\title{
Participative Practices and In-Role Performance in the Korean Local Government: Focusing on an Individual's Perceptions of Human Resource Development Practices
}

\author{
Taejun Cho,* Sue R. Faerman,** and Sujae Yoon****
}

\begin{abstract}
Considering inconsistent results in the extant literature regarding whether participative practices improve performance, we focused on the mediating roles of an individual's perception of human resource development practices, including training and career development, on the relationship between the two constructs. We began by examining the validity of the constructs under the study. Next, using structural equation modeling, we found that an individual's perception of career development fully mediates the relationships between the two participative practices, including participation and empowerment, and in-role performance. In addition, the findings indicated that individuals' perception of training fully mediates the relationship between empowerment and performance, but failed to play a mediating role on the relationship between participation and performance.
\end{abstract}

Keywords: participative practices, human resource development practices, inrole performance

* Taejun Cho is an assistant professor in the Department of Public Administration at the Sangmyung University in Seoul. His research focuses on the integration of managerial and motivational approaches in management processes. E-mail: taejunc@smu.ac.kr.

** Sue R. Faerman is a distinguished teaching professor in the Department of Public Administration and Policy and vice provost for Undergraduate Education at the University at Albany, State University of New York. Her research focuses on the paradoxical elements of managerial and organizational performance, and is also interested in issues associated with women and leadership. E-mail: sfaerman@albany.edu.

*** Sujae Yoon is a research fellow in the Department of Governance and Public Finance at the Korea Institute of Public Administration in Seoul. His research focuses on policy analysis \& evaluation, performance management, and official development assistance programs. E-mail: sjyoon@kipa.re.kr.

Manuscript received May 23, 2012; out for review June 26, 2012; review completed August 13, 2012; accepted August 16, 2012.

The Korean Journal of Policy Studies, Vol. 27, No. 2 (2012), pp. 43-65.

(C) 2012 by the GSPA, Seoul National University 


\section{INTRODUCTION}

Over the past decades, public management research has investigated democratic management practices to solve the problems and limitations of traditional structures in public bureaucracy. Among the democratic approaches to management, this study focuses on participative practices that not only provide employees with opportunities to take part in decision-making processes (e.g., participation) but also transfer authority and responsibility to the employees (e.g., empowerment). While there have been a variety of efforts to introduce participative practices, studies have had inconsistent empirical results with respect to whether these practices improve outcomes, particularly performance (Cotton, 1995; Leana, Locke \& Schweiger, 1990; Wagner, 1994; Wagner \& Gooding, 1987).

One possible reason for these inconsistent results is the existence of factors that may mediate or moderate the relationship between the two variables (Connor, 1992; Wagner \& Gooding, 1987b). While prior studies have argued that some contextual and cognitive factors influence the relationship (Latham, Winters \& Locke, 1994), there have been no conclusive results regarding the exact causes affecting the relationship. This study therefore focuses on individuals' perceptions of human resource development (HRD) practices as a potential mediating factor affecting the relationship. It is based on the expectation that participative practices are appropriate means to increase performance when employees perceive that they have appropriate opportunities to attend HRD programs or their organizations provide these programs to members. Analyzing the reinforcement of an individual's perception of HRD practices on the relationships between participative practices and in-role performance, this study provides an opportunity to examine the role of HRD practices in public management.

\section{LITERATURE REVIEW AND HYPOTHESES}

\section{In-Role Performance}

Researchers in organizational behavior have traditionally focused on in-role behavior. The literature has noted that a second type of behavior, discussed by Katz (1964), referred to as job performance or task performance, is necessary for effective organizational functioning. This type of work performance focuses on role requirements and activities that relate to formal and explicit job descriptions (Borman \& Motowidlo, 1997; Van Dyne \& LePine, 1998; Van Dyne, Cummings \& McLean-Parks, 1995). 
While some studies have criticized the use of this construct to measure performance, most have identified in-role behavior as the primary construct for evaluating an individual's job performance as it relates to prescribed job requirements (Motowidlo, 2000; Van Dyne, Graham \& Dienesch, 1994). In-role behavior is defined as "performance on required duties and responsibilities" (Sparrowe, Liden, Wayne \& Kraimer, 2001, p. 320), "role assignment or formal job requirements" (Williams, 1988, p. 3), or "required or expected behavior" (Van Dyne \& LePine, 1998, p. 108).

\section{Participative Practices}

Organizations have recently tried to develop democratic approaches to management, including participation and delegation, to overcome the problems of hierarchical structures that prevent employees from using their full range of abilities (Huselid, 1995). Among the various practices used by organizations, we discuss here participation and empowerment.

\section{Participation}

Participation in decision-making processes is defined as an organizational practice that involves employees at lower levels of an organizational hierarchy in decisionmaking processes (Lowin, 1968). In particular, it is defined as "a process in which two or more parties influence each other in making certain plans, policies, and decisions" (French, Israel \& As, 1960, p. 3) or a process whereby "an individual who is affected by decisions influences the making of those decisions" (Connor, 1992, p. 219). Researchers have considered participation as a practice designed to improve employees' satisfaction, motivation, and performance (Kearney \& Hays, 1994; Steel \& Lloyd, 1988).

Although researchers have consistently found that participation leads to increases in satisfaction and intrinsic motivation, there have been inconsistent results regarding the relationship between participation and performance (Cotton, 1995; Leana et al., 1990). Researchers supporting a positive relationship between the two constructs, such as Cotton et al. (1988), have argued that different studies have had varying results regarding the relationships between these two constructs because different researchers have examined different forms of participative decision-making. Leana et al. (1990) have criticized this argument and asserted that the classification system for different forms of participative decision making used in Cotton et al.'s (1988) study was flawed and that their sampling of research was biased. In addition, meta-analyses have reported that participation statistically increases performance but the size of the impact is rather 
modest (Wagner, 1994).

In an effort to explain these inconsistent results, several studies have examined contingent and cognitive factors that may have a moderating or mediating affect on the relationship (Latham et al., 1994; Miller \& Monge, 1986; Sagie \& Koslowsky, 2000). Thus, there remain some empirical debates regarding the relationship between the two constructs. However, a conceptual consensus has developed that participation is an option for improving performance because employees who have opportunities to take part in decision-making processes are more likely to develop their managerial abilities and skills than those who work under control-based management.

\section{Empowerment}

Empowerment is defined as the process of transferring authority and responsibility for making routine and important decisions to employees working at lower levels of the organizational hierarchy (Ledford \& Lawler, 1996). In particular, it is defined as "activities or degree of discretion attached to specific jobs or by teams dealing with groups of jobs" (Cunningham, Hyman \& Baldry, 1996, p. 145) and "being proactive and self-sufficient in assisting an organization to achieve its goals" (Herrenkohl, Judson \& Heffner, 1999, pp. 373-378). Empowerment has been widely accepted as a means to increase trust, which in turn increases individual performance, motivation, and satisfaction (Dirks \& Ferrin, 2001).

Based on these findings, the management literature has noted that empowerment would be effective when a work unit is operated as a self-regulated team, allowing management authority and responsibility to employees. In fact, empowerment has been conceptually linked to self-managing work teams, defined as "task structures where independent workers self-regulate their behavior around relatively whole tasks" (Cummings \& Griggs, 1977, p. 87). Thus, the key point of self-managing work teams is that team members have the discretion to make decisions and to implement tasks (Langfred, 2004), and have the ability to organize their work and goals (Hackman, 1986). The literature has recognized empowerment as a means to improve work-related outcomes, including loyalty, satisfaction, and performance (Gómez \& Rosen, 2001; Niehoff, Moorman, Blakely \& Fuller, 2001). Nevertheless, public management researchers have paid little attention to empirical studies of the effect of empowerment on work-related outcomes, but have focused on the role of empowerment in the processes of the reinventing-government movement. 


\section{Human Resource Development Practices ${ }^{1}$}

To enhance employees' development with respect to management knowledge and skills, organizations have introduced a variety of HRD practices to improve workrelated outcomes. ${ }^{2}$ Here we discuss training and career development as two HRD practices.

\section{Training}

Training is defined as an organization's planned effort to improve employees' jobrelated knowledge and skills through "formal or informal learning necessary for the performance of specific job tasks" (Myers, 1992, p. 1049). As a short-term HRD approach (Butler, Ferris \& Napier, 1991), organizations need to provide training programs to help employees become more competent, as well as to help them become more motivated to learn (Guthrie \& Schwoerer, 1994). A number of scholars have argued that training improves desired work-related outcomes and decreases employee turnover (Delaney \& Huselid, 1996; Huselid, 1995; Kraiger, McLinden \& Casper, 2004; Lawler, Mohrman \& Ledford, 1998; Tannenbaum, Mathieu, Salas \& CannonBowers, 1991).

Opponents of training programs have argued that these programs are expensive and may in fact lead to conflict between employees and managers (Kraiger, 2003). Although some studies have argued that training is not an effective HRD practice and does not

1. The processes of HRDM intervention consist of four stages, including assessment, design, implementation, and evaluation. At the first stage, an organization assesses the need for the development programs. To be sure, an organization classifies and prioritizes employees' needs for the development in the first step. Second, an organization designs for the HRD interventions. This stage includes defining objectives, developing plan, acquiring materials, selecting trainers and method, and scheduling the program and intervention. Third, an organization focuses on implementation of HRD programs. Finally, there is an evaluation process. At this stage, it includes selecting evaluation criteria, determining evaluation design, conducting evaluation, and interpreting results.

2. Researchers have reached a consensus that HRM practices may be broadly categorized into three types as follows (Delaney \& Huselid, 1996; Huselid, 1995). First, the literature focuses on practices that develop employee capacity, career, and skill. It includes training, career development, and organization development. Second, the HRM research has studied the practices encouraging employee motivation, such as performance appraisal and incentive compensation. Finally, researchers in HRM have classified the practices that provide authority and responsibility to employees in decision-making processes, such as selfmanaging work team. 
improve outcomes, almost all human resource managers argue that training programs play a positive role because they develop employees' competence and motivation for learning (Salas \& Cannon-Bowers, 2001). Pynes (2004, p. 284) notes that training focuses on "improving an individual's level of awareness, increasing an individual competency in one or more areas of expertise, or increasing an individual's motivation to perform his or her job well." Based on this review, this study hypothesized that training provides employees opportunities to develop new managerial abilities, commitment, and motivation, and made the following hypothesis.

Hypothesis 1: Training positively affects an individual's in-role performance.

Additionally, this study examined whether an individual's perception of training mediates the relationships between the two participative practices and in-role performance. As pointed out earlier, researchers have reported inconsistent results regarding the relationship between participative practices and performance, and have tried to find mediating variables affecting the relationship. An individual's perception of training, as one possible mediating variable in the relationship, is examined in this study because it provides opportunities for continuous learning and improvement, which help the organization to maintain employees as strong human resource assets. Supporting this argument, Liden and Tewksbury (1995) note that for participative practices to be effective, the organization's leaders and employees need to be trained to operate in nonhierarchical situations. In addition, Cunningham et al. (1996) note that participative practices need trained employees who have sufficient knowledge and ability to engage in decision-making and implementing processes. Thus, we proposed the following hypotheses.

Hypothesis 2a: Participation positively affects an individual's in-role performance through training.

Hypothesis 2b: Empowerment positively affects an individual's in-role performance through training.

\section{Career Development}

Hall (1987, p. 1) defines career as "the sequence of individually perceived workrelated experiences and attitudes that occur over the span of a person's work life." Based on this definition, career development has been identified as "a process requiring individuals and organizations to create a partnership that enhances employees' knowledge, skills, competencies, and attitudes required for their current and future job 
assignments" (Gilley, Eggland, \& Gilley, 2002, p. 94). Thus, career development is seen as an important HRD practice that is designed to develop and increase employees' knowledge and abilities related to their organizational activities (Chen, Chang \& Yeh, 2006), as well as to improve individual performance and commitment (Hall \& Hall, 1976; Wellbank, Hall, Morgan \& Hammer, 1978).

The literature has noted that training and career development have similar definitions and functions, and that the two practices are recommended as practical ways to prepare and manage changes in internal and external environments, including technological development and modification of internal policies. These programs offer employees the opportunity to develop their abilities and knowledge based on a shortor long-term plan (Butler et al., 1991). Arguably, the difference between short- and long-term planning for employee development can be used as a basis for differentiating between training and development. Thus, career development is generally defined in terms of opportunities designed to improve employees' future competencies, whereas training provides employees to the knowledge for their current positions (Pynes, 2004). In addition, both provide opportunities to improve employees' motivation and performance (Pynes, 2004). Based on this discussion, we see career development programs as providing opportunities to improve employees' knowledge and competence for future positions. Thus, this study hypothesized that individuals who take part in career development programs develop administrative techniques and skills that improve their in-role performance.

Hypothesis 3: Career development positively affects an individual's in-role performance.

Additionally, this study examined whether an individual's perception of career development mediates the two practices and in-role performance. As Cunningham et al. (1996) note, career development is one approach for empowering employees and building their capacity to participate in decision-making processes, because employees involved in HRD practices are more likely to have appropriate information and knowledge for maximizing the effects of these participative practices. Thus, we proposed the following hypotheses.

Hypothesis 4a: Participation positively affects an individual's in-role performance through career development.

Hypothesis 4b: Empowerment positively affects an individual's in-role performance through career development. 


\section{METHODOLOGY}

\section{Sample}

Using a multistage cluster sampling approach, we collected data from public employees working in the largest local government in Korea. This sampling method was employed to save time and reduce costs associated using the entire population of employees working for this government, even though it may lead to some sampling errors (Babbie, 2001). We selected eight bureaus that provide a list of all employees on their web sites and randomly distributed questionnaires to 40 employees in each bureau. Of the 320 employees who received a questionnaire, 165 returned usable responses that were included in the analysis.

\section{Variables}

All variables were measured using a seven-point Likert scale. As the dependent variable, in-role performance was measured using Williams and Anderson's (1991) seven-item scale. The reliability of this measure was previously reported as 0.91 (Williams \& Anderson, 1991). To measure participation, we adopted Delery and Doty's (1996) four-item scale, reported to have achieved reliability of 0.80. Empowerment was measured using Nyhan's (1994) five-item scale, reliability reported as 0.78 . This study also adopted Delery and Doty's (1996) four-item scale for measuring training (Cronbach's alpha $=0.83$ ). Career development was measured using Smith's (1995) four-item scale measuring the organization's interest in career development and individual development, respectively. The internal reliabilities of these measures have been previously reported as 0.88 and 0.83 , respectively (Smith, 1995). The appendix provides all measurement items.

\section{Data Analysis}

Structural equation modeling (SEM) was conducted to analyze the causal relationships. SEM allows researchers to simultaneously examine the covariance structures regarding the relationships among the constructs while considering measurement errors (Kline, 2005). Before conducting the causal analysis, we conducted confirmatory factor analyses (CFA) to verify each construct's validity, as well as to confirm the construct's proposed factor structure in the measurement model. This study employed a number of criteria to assess the model fit, including both absolute and incremental fit indices (Jaccard \& Wan, 1995; Tabachnick \& Fidell, 2001). 


\section{RESULTS}

\section{Descriptive Statistics}

More than half of the respondents were male (61.2 percent). With respect to age, the modal response was 31-40 years (48.5 percent). The modal response for organizational tenure was 11-15 years (23.0 percent). Most respondents were employed at the operational management level (rank 6 or $7 ; 65.5$ percent) or the street level (rank 8 or 9; 32.1 percent). Almost two-thirds (63.6 percent) had obtained a bachelor's degree. Table 1 provides participants' demographic information.

Table 1. Demographic Information on Participants

\begin{tabular}{l|l|r|c}
\hline \multirow{3}{*}{ Gender } & Female & Total & Percent \\
\cline { 2 - 4 } & Male & 64 & 38.8 \\
\hline \multirow{4}{*}{ Age } & $21-30$ years & 101 & 61.2 \\
\cline { 2 - 4 } & $31-40$ years & 26 & 15.8 \\
\cline { 2 - 4 } & 41-50 years & 80 & 48.5 \\
\cline { 2 - 4 } & Over 51 years & 50 & 30.3 \\
\hline \multirow{4}{*}{ Years of experience } & Less than 5 years & 9 & 5.5 \\
\cline { 2 - 4 } & 6-10 years & 49 & 29.7 \\
\cline { 2 - 4 } & 11-15 years & 22 & 13.3 \\
\cline { 2 - 4 } & 16-20 years & 38 & 23.0 \\
\cline { 2 - 4 } & More than 20 years & 34 & 20.6 \\
\hline \multirow{5}{*}{ Hierarchical level } & Upper management (rank 1-3) & 1 & 13.3 \\
\cline { 2 - 4 } & Middle management (rank 4-5) & 3 & 0.6 \\
\cline { 2 - 4 } & Operational management (rank 6-7) & 108 & 65.8 \\
\cline { 2 - 4 } & Street-level employees (rank 8-9) & 53 & 32.1 \\
\hline \multirow{5}{*}{ Education } & High school & 23 & 13.9 \\
\cline { 2 - 4 } & College & 23 & 13.9 \\
\cline { 2 - 4 } & Bachelor's degree & 105 & 63.6 \\
\cline { 2 - 4 } & Master's degree & 14 & 0 \\
\cline { 2 - 4 } & Doctorate & & 8.5 \\
\hline
\end{tabular}

Table 2 shows the descriptive statistics and reliabilities for the researched measures. All correlation coefficients were statistically significant at the level of 0.01 . Almost all 
Table 2. Correlation and Reliabilities

\begin{tabular}{l|c|c|c|c|c|c|c}
\hline & Mean & S.D. & 1 & 2 & 3 & 4 & 5 \\
\hline 1. Training & 3.71 & 1.11 & $(0.85)$ & & & & \\
\hline 2. Career development & 4.17 & 1.03 & 0.51 & $(0.89)$ & & & \\
\hline 3. Participation & 4.29 & 1.18 & 0.36 & 0.71 & $(0.90)$ & & \\
\hline 4. Empowerment & 4.16 & 0.98 & 0.50 & 0.59 & 0.61 & $(0.88)$ & \\
\hline 5. In-role performance & 5.25 & 0.81 & 0.32 & 0.35 & 0.29 & 0.24 & $(0.92)$ \\
\hline
\end{tabular}

* Note: All correlations are significant at the 0.01 level. Cronbach's alpha is presented in parentheses.

correlations were moderate, while the coefficient between training and participation was fairly high $(r=0.71)$. Additionally, all scale reliabilities met the threshold $(0.70)$ suggested by Nunnally and Berstein (1994); they ranged from 0.85 to 0.92 .

\section{Testing Model Fit and Construct Validity}

CFA was employed to examine the construct validity of the four-item scale used to measure participation and model fit. In assessing factor loadings of the construct, we found that all four items' standardized regression weights achieved the ideal threshold (0.70) proposed by Hair, Black, Anderson, and Tatham (2006), and their weights were statistically significant at the level of 0.001 . Additionally, almost all model fit indices achieved the threshold $(\mathrm{RMR}=0.043$; GFI $=0.969 ; \mathrm{CFI}=0.980 ; \mathrm{NFI}=0.975)$, although one fit index (RMSEA $=0.158$ ) did not meet the expectation.

The CFA for the five-item measure of empowerment indicated that all fit indices achieved the thresholds $(\mathrm{RMR}=0.041$; $\mathrm{GFI}=0.967$; $\mathrm{RMSEA}=0.098 ; \mathrm{CFI}=0.982$; $\mathrm{NFI}=0.971)$. While RMSEA did not meet the ideally recommended cutoff value, it satisfied the acceptable level (1.00) proposed by Hair et al. (2006). With respect to construct validity, almost all factor scores of each item met the ideal level (0.70), but the fifth item's standardized regression weight was reported as 0.64 . The unstandardized regression weights for all items were statistically significant $(p<0.001)$.

The result of the CFA examining the four-item measure of training indicated that RMSEA (0.251) and normed $\chi^{2}$ (11.299) did not meet acceptable cutoff values. However, other fit indices did achieve appropriate threshold values $(\mathrm{RMR}=0.078$; $\mathrm{GFI}=0.946 ; \mathrm{CFI}=0.931 ; \mathrm{NFI}=0.926$ ). In addition, almost all items' standardized factor loadings exceeded the ideal value $(0.70)$, except for the fourth one $(0.68)$. Because the two absolute fit indices did not meet the thresholds in the basic model, this study employed modification processes to improve model fits. The modification index (MI) in SEM suggested that a two-way arrow (covariance) should be added 
between the first and fourth items (e1↔e4) because these items' error terms covariated. Following the process, all fit indices for the revised model showed improvement over the basic model. In particular, normed $\chi^{2}(0.335)$ and RMSEA (0.000) reached appropriate cutoff values. In addition, other fit indices achieved the recommended levels in the final model (RMR $=0.012$; GFI $=0.999$; $\mathrm{CFI}=1.000 ; \mathrm{NFI}=0.999)$. Regarding the factor loadings in this model, we found that all items' standardized regression weights exceeded the cutoff value. In addition, the fourth item improved from 0.68 to 0.79 .

The CFA conducted on the four-item career development scale indicated that all fit indices achieved the recommended threshold values $(\mathrm{RMR}=0.023$; GFI $=0.986$; RMSEA $=0.095 ; \mathrm{CFI}=0.993$; NFI $=0.988$ ). Another fit index for measuring the absolute fit, normed $\chi^{2}$ (2.475) also met the ideal level (less than 3.0). Additionally, all factor loadings were statistically significant at the level of 0.001 , and standardized regression weights achieved the appropriate cutoff value.

CFA of the seven-item in-role performance scale indicated that some model fit indices achieved the recommended threshold values $(\mathrm{RMR}=0.052 ; \mathrm{CFI}=0.911)$, whereas others did not (normed $\chi^{2}=6.924$; GFI $=0.868$; RMSEA $=0.190$; NFI = 0.898 ). The poor model fit may be the result of high covariance between the sixth and seventh items' error terms ( $\mathrm{e} 6 \leftrightarrow \mathrm{e} 7$; MI = 61.86) in the basic model. Although the fit indices were poor for this model, each item's standard regression weight was well above the ideal level, except for the fifth item, which was reported as 0.55. Based on these results, we revised the model, adding a two-way arrow between the sixth and seventh error terms to improve the model fit. In the revised model, model fit indices were significantly improved (normed $\chi^{2}=1.849$; RMR $=0.028$; GFI $=0.959$; RMSEA $=0.072 ; \mathrm{CFI}=0.988 ; \mathrm{NFI}=0.975)$. In addition, all items' standardized factor loadings were above the cutoff, and their unstandardized regression weights were statistically significant $(p<0.001)$. The correlation between the two error terms was reported as 0.61 .

\section{Testing Causal Paths}

Structural equation modeling was employed to test the causal relationships among the constructs. Before testing the research hypotheses, we discussed the basic model's fit indices. In the model of causal paths, the results indicated that some model fit indices were acceptable (normed $\chi^{2}=2.212$; RMSEA $=0.086$; CFI $=0.902$ ), whereas others did not meet the recommended cutoff values $(\mathrm{RMR}=0.108$; GFI $=0.794$; NFI = 0.836). However, all standardized regression weights of the items met the threshold (see Figure 1). Additionally, the results indicated that all observed indicators 
Figure 1. Path Analysis

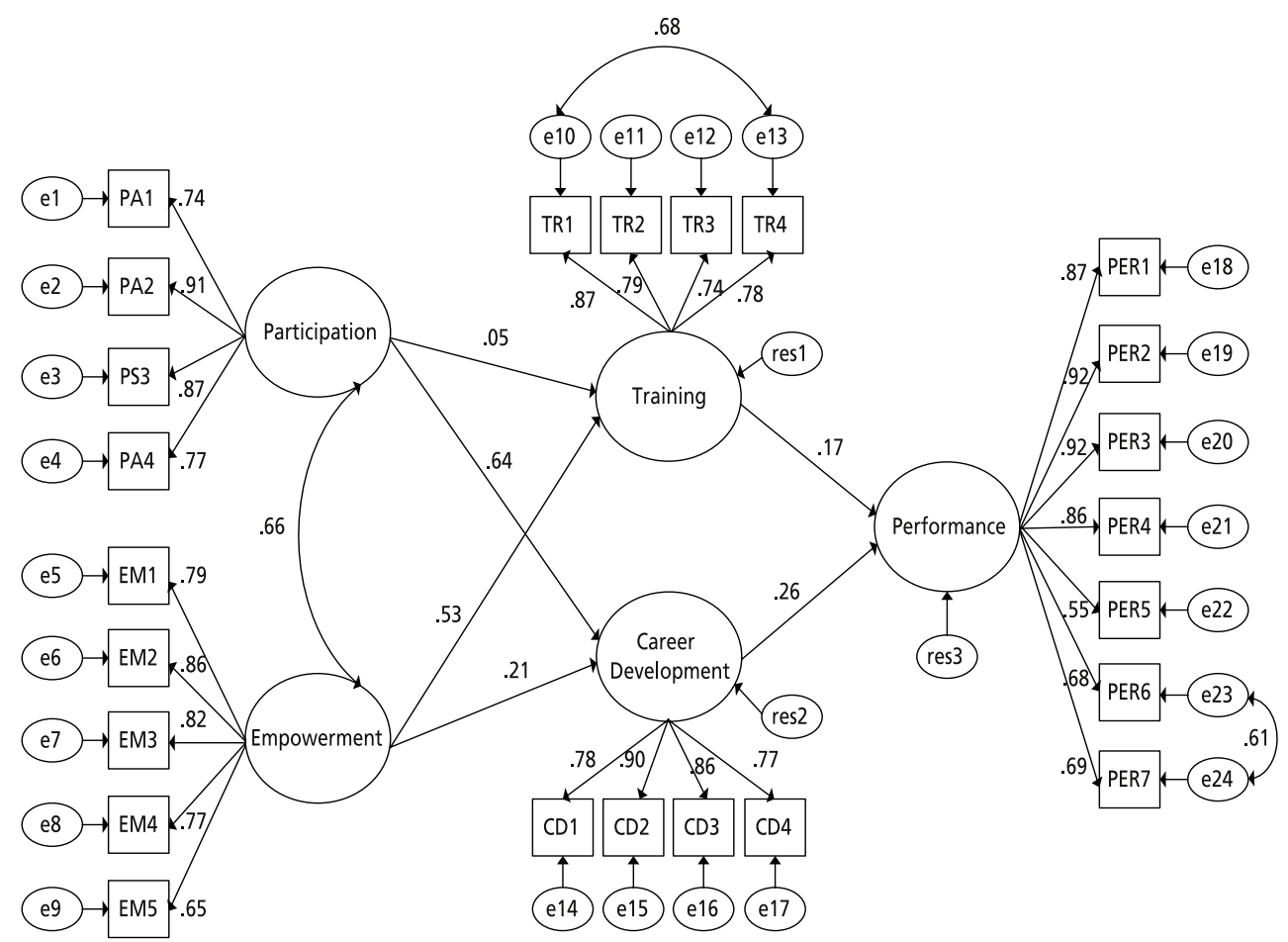

Note: Standardized regression weights and factor loadings are presented.

appropriately loaded on their first-order construct $(p<0.001)$.

As seen in Figure 1, the five path coefficients of the six hypothesized relationships were statistically significant. Training and career development were positively related to in-role performance. In particular, the standardized regression weight for the path from training to performance was 0.17 (unstandardized weight $=0.15, p<0.05$ ) (hypothesis 1); standardized regression weight for the path from career development to performance was 0.26 (unstandardized weight $=0.28, p<0.01$ ) (hypothesis 3 ).

With respect to the mediating role of training, the results indicated that training fully mediates the relationship between empowerment and performance (hypothesis $2 b$ ). That is, the total effect of empowerment on performance was 0.09 , which resulted simply from the indirect effect through training $(0.53[p<0.01$, empowerment $\rightarrow$ training $] \times 0.17$ [ $p<0.05$, training $\rightarrow$ performance $]$ ). In addition, the path from empowerment to performance through training was statistically significant (see Table 2). However, we found that training did not fully mediate the relationship between participation and performance (hypothesis $2 \mathrm{a}$ ) because the path from participation to 
training was statistically nonsignificant (unstandardized coefficient $=0.06$, n.s.).

Regarding the mediating role of career development, the results indicated that career development fully mediates the relationship between empowerment and performance (hypothesis 4b). More specifically, the total effect of empowerment on performance was 0.06 , which was a result of the indirect effect through career development $(0.21[p$ $<0.01$, empowerment $\rightarrow$ career development $] \times 0.26[p<0.01$, career development $\rightarrow$ performance]) (see also Table 3). In addition, this study found that career development fully mediates the relationship between participation and performance (hypothesis 4a). The total effect of participation on performance was 0.17 , which was a result of the indirect effect through career development $(0.64[p<0.001$, participation $\rightarrow$ career development $] \times 0.26[p<0.01$, career development $\rightarrow$ performance $]$ ) (see also Table 3 ).

Examining the baseline model, we found that the five paths met the expectations presented in this study's hypotheses. For further analysis, we examined a nested model, which can add or delete some paths from the original one, to determine whether the original model is the best model. Adding two paths-one from participation directly to performance and one from empowerment directly to performance-we examined whether the participative practices directly influence in-role performance. That is, the

Table 3. Direct, Indirect, and Total Effects

\begin{tabular}{|c|c|c|c|c|c|}
\hline & & Participation & Empowerment & Training & $\begin{array}{c}\text { Career } \\
\text { development }\end{array}$ \\
\hline \multirow{3}{*}{ Direct effect } & Training & $\begin{array}{l}0.06 \\
\text { (n.s.) }\end{array}$ & $\begin{array}{c}0.64 \\
(p<0.001)\end{array}$ & & \\
\hline & $\begin{array}{c}\text { Career } \\
\text { development }\end{array}$ & $\begin{array}{c}0.57 \\
(p<0.001)\end{array}$ & $\begin{array}{c}0.20 \\
(p<0.05)\end{array}$ & & \\
\hline & $\begin{array}{c}\text { In-role } \\
\text { performance }\end{array}$ & & & $\begin{array}{c}0.15 \\
(p<0.05)\end{array}$ & $\begin{array}{c}0.28 \\
(p<0.001)\end{array}$ \\
\hline \multirow{3}{*}{ Indirect effect } & Training & & & & \\
\hline & $\begin{array}{c}\text { Career } \\
\text { development }\end{array}$ & & & & \\
\hline & $\begin{array}{c}\text { In-role } \\
\text { performance }\end{array}$ & $\begin{array}{l}0.17 \\
\text { (n.s.) }\end{array}$ & $\begin{array}{c}0.15 \\
(p<0.05)\end{array}$ & & \\
\hline \multirow{3}{*}{ Total effect } & Training & $\begin{array}{l}0.06 \\
\text { (n.s.) }\end{array}$ & $\begin{array}{c}0.64 \\
(p<0.001)\end{array}$ & & \\
\hline & $\begin{array}{c}\text { Career } \\
\text { development }\end{array}$ & $\begin{array}{c}0.57 \\
(p<0.001)\end{array}$ & $\begin{array}{c}0.20 \\
(p<0.05)\end{array}$ & & \\
\hline & $\begin{array}{c}\text { In-role } \\
\text { performance }\end{array}$ & $\begin{array}{l}0.17 \\
\text { (n.s.) }\end{array}$ & $\begin{array}{c}0.15 \\
(p<0.05)\end{array}$ & $\begin{array}{c}0.15 \\
(p<0.05)\end{array}$ & $\begin{array}{c}0.28 \\
(p<0.001)\end{array}$ \\
\hline
\end{tabular}

Note: Unstandardized estimates are provided. 
nested model examined the partial mediating roles of HRD practices. The findings from this analysis indicated that the two paths from participative practices to performance were statistically nonsignificant. In particular, the path from participation to performance was reported as 0.12 (unstandardized path $=0.12$, n.s.); the path from empowerment to performance was reported as -0.04 (unstandardized path coefficient $=0.05$, n.s.). Based on the results, we found that the two participative practices did not directly improve in-role performance.

With respect to the model fit of the nested model, some model fit indices met the thresholds (normed $\chi^{2}=2.228$; RMSEA $=0.087$; $\mathrm{CFI}=0.901$ ), whereas others did not meet the cutoffs $(\mathrm{RMR}=0.108 ; \mathrm{GF}=0.795 ; \mathrm{NFI}=0.836)$. As one criterion to compare the two models, chi-square difference statistics $\left(\Delta \chi^{2}\right)$ of the nested model were examined $\left(\chi^{2}=536.91, d f=241\right)$. Comparison of the original and nested models indicated that the difference was not statistically significant; the original model's chi-square statistic was reported as $537.53(d f=243)$, and its $\Delta \chi^{2}$ was nonsignificant considering differences in degree of freedom $(d f)$. In sum, based on the comparison of the two models, we conclude that participative practices are not appropriate means to improve performance directly, as some scholars have argued.

\section{DISCUSSION}

\section{Implications}

The results of this study suggest some implications for both public management researchers and practitioners. First, the findings indicated that the two HRD practices improve in-role performance. The extant literature in public management has mainly focused on participative practices to solve the problems of hierarchical structures as well as to improve outcomes. However, few empirical studies have been conducted to test this assumed relationship, and scholars have not reached a consensus on whether these practices positively affect performance. We found that participation and empowerment did not directly affect in-role performance. This result indicates that structural changes seeking to promote democratic values in organizational processes would not directly increase in-role performance in public bureaucracy. To be sure, some government organizations have introduced participative practices to improve motivation and performance. Although they have been interested in the practices, they have not focused on employees' development, which has been required to utilize the participative practices. This study argues that there is a need to develop employees' abilities and competence to maximize the effect of participation and empowerment. That is, we expect 
that the success of participative practices in an organization depends on organizational members' abilities and competence. In contrast to the above result, this study found that the two HRD practices positively relate to in-role performance. To be sure, research has rarely focused on the effect of HRD practices on performance in public management. That is, rather than focusing on participative practices as the primary approach to increase outcomes in an organization, there is a need to emphasize HRD programs that support such practices. When an organization provides more opportunities to develop its employees' skills and abilities for both current and future job demands, we expect this development to be an important factor in improving organizational performance. Following this argument, our findings suggest that there may be a need for organizations to invest time and resources to develop their employees' skills and abilities to perform effectively in their jobs. In sum, this study found that HRD practices that focus on an individual's management development in terms of ability, skills, and competence are more likely to improve in-role performance. This study assumes that participative practices would be factors to increase in-role performance; however, it is not an antecedent to improving performance in an organization. It requires organizational members' management development to improve in-role performance.

Second, the findings indicated that there is a need to combine participative practices with HRD practices to improve in-role performance. As noted above, the public management literature has primarily emphasized participative practices as one means to improve performance, although the effects of such practices have been reported as minimal or nonsignificant. Supporting these results, we also found that participation and empowerment did not statistically improve in-role performance. However, we found that participative practices did improve in-role performance through HRD practices at the basic model in this research. Thus, the only significant paths between participative practices and performance included training and career development as potential factors to affect the relationships. Moreover, when we examined the nested model in this study, we found that the two participative practices only indirectly affected in-role performance. Supporting the full mediating effect of career development, the findings suggest that we need to consider the role of career development when introducing participative practices. That is, rather than simply allowing employees to have responsibility and authority in decision-making and management processes, there is a need to provide opportunities to employees to participate in career development programs when attempting to implement empowerment. Our findings empirically supported Cunningham et al.'s (1996) argument that HRD practices may need to be combined with participative practices in order to ensure the impact of the latter on work unit outcomes. Without first providing appropriate HRD programs to employees, participative practices do not seem to improve in-role performance.These findings and theoretical 
implications also suggest some practical implications for managers in public sector organizations. First, participation and empowerment have been widely discussed as appropriate practices for improving performance in public management, although their effects have rarely been empirically tested. Additionally, research on the two practices has reported inconsistent results regarding the relationship. The findings from the nested model in this study indicated that the two practices did not improve in-role performance. As other researchers have argued, the practices may increase an individual's job satisfaction, but there is little empirical evidence that they increase individual performance. Thus, leaders in public sector organizations need to acknowledge the limited role of these practices to increase performance, and to consider HRD practices as an important prerequisite increasing performance. That is, in practice, there is a need to combine other HRM practices, such as HRD practices to reinforce the relationship between participative practices and performance.

This suggests that managers in public organizations need to consider the development of human resources as an investment, rather than a cost, as it is most often viewed. As the findings indicate, HRD practices directly improve performance, as well as play a mediating role affecting the relationships between the participative practices and performance. However, leaders in public management have paid little attention to these practices because HRD programs are seen as costly in terms of both monetary resources and employee time. Although there are costs associated with the implementation of HRD programs, managers in public sector organizations need to approach them as an investment that not only leads to improved performance but also develops employees' ability to work with new management practices, including participation and empowerment.

\section{Limitations of the Study and Directions for Future Research}

Although these findings suggest some important implications regarding HRM practices in public management, one also considers the limitations of this study. First, we employed a number of modification processes in SEM to improve the construct validity statistics and model fits. While the literature commonly accepts modification processes, SEM researchers also argue that the modifications should be based on theoretical reasoning. In this study, we did not identify the theoretical logic conducting the processes. As a result, the revised model in this study may have resulted in a loss of information relative to the original measurement model, which we developed from the extant literature. This suggests that there is a need to conduct additional research with a different sample to verify model fit.

Second, we collected the data at a single point in time. Thus, this study cannot 
definitely determine the causal directions of the relationships. For example, one could expect a different causal direction with HRD practices leading to increases in performance while participative practices serve as the mediating variable. Alternatively, one may expect that HRD practices moderate the relationship between participative practices and in-role performance. To overcome these limitations, future research might collect longitudinal data in order to examine the causal directions in the hypothesized framework, as well as to examine the moderating effect of HRD practices.

Third, all data used in this study were obtained from self-reported survey and subjective measures, which may result in social desirability effects and biased responses. In particular, we collected data regarding individuals' perceptions of HRD practices, but did not obtain objective data, such as attendance at HRD programs during respondents' careers. Thus, we should be cautious in interpreting the results regarding the impact of HRD programs on performance, because almost all researchers and practitioners in public management have argued for the use of training programs in the public sector.

Future research should employ objective or multisource data to measure some of the constructs, particularly HRD practices and in-role performance, to solve the problems of social desirability and common-method variance. Additionally, future research needs to consider complementarities between participation, empowerment, and training - for example, in terms of communications, presentation, and negotiation skills. In addition, it needs to control the relevant variables, including context of system, to affect the relationship between participative practices and in-role performance. Finally, future research should focus on developing measurement items for complex relationships between the variables. Although the measurement items used in this study were developed in prior studies, they have a limited capacity to accurately measure the meaning of the variables.

\section{CONCLUSION}

HRM practices have been considered a key management approach to increase performance at both the individual and organizational levels. With an emphasis on NPM, in particular, researchers and practitioners in public management have focused on participation-based HRM practices to improve performance. However, some studies have reported inconsistent results regarding the direct effect of participative practices on performance. Given that HRD practices have received little attention in public management, although these practices may be appropriate means to increase outcomes, this study examined whether an individual's perception of HRD practices play a mediating role in the relationship between participative practices and in-role performance. 
The findings indicate that career development fully mediates the relationships between both participative practices and performance. Training, however, only played a mediating role on the relationship between empowerment and performance in this study, and its mediating effect on the relationship between participation and in-role performance was found to be statistically nonsignificant.

Based on these results, the findings suggest that participative HRM practices do not directly lead to increases in performance, but these practices did lead to improved outcomes through HRD practices. Additionally, the findings suggest that HRD practices directly improve in-role performance. Given the dual role that HRD practices can play in improving organizational performance, the results of this study suggest that HRD practices need to be considered as an important first step when government organizations introduce participation-based practices to improve performance.

\section{REFERENCES}

Babbie, E. 2001. The practice of social research. Belmont, CA: Wadsworth/Thomson Learning.

Borman, W. C., \& Motowidlo, S. J. 1997. Task performance and contextual performance: The meaning for personnel selection research. Human Performance, 10(1): 99-109.

Butler, J. E., Ferris, G. F., \& Napier, N. K. 1991. Strategy and human resources management. Cincinnati, OH: South-Western Publishing Co.

Chen, T., Chang, P., \& Yeh, C. 2006. The effects of career development programs on R\&D personnel in Taiwan. Asia Pacific Journal of Human Resources, 44(3): 318-341.

Connor, P. E. 1992. Decision-making participation patterns: The role of organizational context. Academy of Management Journal, 35(1): 218-231.

Cotton, J. L. 1995. Participation's effect on performance and satisfaction: A reconsideration of Wagner. Academy of Management Review, 20(2): 276-278.

Cotton, J. L., Vollrath, D. A., Froggatt, K. L., Lengnick-Hall, M. L., \& Jennings, K. R. 1988. Employee participation: Diverse forms and different outcomes. Academy of Management Review, 13(1): 8-22.

Cummings, T. G., \& Griggs, W. H. 1977. Worker reactions to autonomous work group: Conditions for functioning, differential effects, and individual differences. Organization \& Administrative Sciences, 7(4): 87-100.

Cunningham, I., Hyman, J., \& Baldry, C. 1996. Empowerment: The power to do what? Industrial Relations Journal, 27(2): 143-154. 
Delaney, J. T., \& Huselid, M. A. 1996. The impact of human resource management practices on perceptions of organizational performance. Academy of Management Journal, 39(4): 949-969.

Delery, J. E., \& Doty, D. H. 1996. Mode of theorizing in strategic human resource management: Test of universalistic, contingency, and configurational performance predictors. Academy of Management Journal, 39(4): 802-835.

Dirks, K. T., \& Ferrin, D. L. 2001. The role of trust in organizational settings. Organization Science, 12(4): 450-467.

French, J. R. P., Israel, J., \& As, D. 1960. An experiment on participation in a Norwegian factory. Human Relations, 13(1): 3-19.

Gilley, J. W., Eggland, S. A., \& Gilley, A. M. 2002. Principles of human resource management. Cambridge: Perseus Books.

Gómez, C., \& Rosen, B. 2001. The leader-member exchange as a link between managerial trust and employee empowerment. Group \& Organization Management, 26(1): 53-69.

Guthrie, J. P., \& Schwoerer, C. E. 1994. Individual and contextual influences on selfassessed training needs. Journal of Organizational Behavior, 15(5): 405-422.

Hackman, J. R. 1986. The psychology of self-management in organizations. In M. S. Pallack \& R. O. Perloff (eds.), Psychology and work: Productivity, change, and employment (pp. 85-136). Washington, DC: American Psychological Association.

Hair, J. F., Black, B., Anderson, R. E., \& Tatham, R. L. 2006. Multivariate data analysis (6 $6^{\text {th }}$ ed.). Upper Saddle River, NJ: Pearson Prentice Hall.

Hall, D. T. 1987. Introduction: An overview of current CD theory, research, and practice. In D. T. Hall \& Associates (eds.), Career development in organizations (pp. 1-20). San Francisco: Jossey-Bass.

Hall, D. T., \& Hall, F. S. 1976. What's new in career management. Organizational Dynamics, 5(2): 17-33.

Herrenkohl, R. C., Judson, G. T., \& Heffner, J. A. 1999. Defining and measuring employee empowerment. Journal of Applied Behavioral Science, 35(3): 373-389.

Huselid, M. A. 1995. The impact of human resource management practices on turnover, productivity, and corporate financial performance. Academy of Management Journal, 38(3): 635-672.

Jaccard, J., \& Wan, C. K. 1995. LISREL approaches to interaction effects in multiple regression. Thousand Oaks, CA: SAGE.

Katz, D. 1964. The motivational basis of organizational behavior. Behavioral Science, 9: 131-146.

Kearney, R. C., \& Hays, S. W. 1994. Labor-management relations and participative decision making: Toward a new paradigm. Public Administration Review, 
54(1): 44-51.

Kline, R. B. 2005. Principles and practices of structural equation modeling. New York: Guilford Press.

Kraiger, K. 2003. Perspectives on training and development. In W. C. Borman, D. R. Ilgen, \& R. J. Klimoski (eds.), Handbook of psychology: Industrial and organizational psychology (pp. 171-192). Hoboken, NJ: John Wiley \& Sons.

Kraiger, K., McLinden, D., \& Casper, W. J. 2004. Collaborative planning for training impact. Human Resource Management, 43: 337-351.

Langfred, C. W. 2004. Too much of a good thing? Negative effects of high trust and individual autonomy in self-managing teams. Academy of Management Journal, 47(3): 385-399.

Latham, G. P., Winters, D. C., \& Locke, E. A. 1994. Cognitive and motivational effects of participation: A mediator study. Journal of Organizational Behavior, 15(1): 49-63.

Lawler, E. E., Mohrman, S. A., \& Ledford, G. E. 1998. Strategies for high performance organizations. San Francisco: Jossey-Bass Publishers.

Leana, C. R., Locke, E. A., \& Schweiger, D. M. 1990. Fact and fiction in analyzing research on participative decision making: A critique of Cotton, Vollrath, Froggatt, Lengnick-Hall, and Jennings. Academy of Management Review, 15(1): 137-146.

Ledford, G. E., \& Lawler, E. E. 1996. Research on employee participation. Academy of Management Review, 19(4): 633-636.

Liden, R. C., \& Tewksbury, T. W. 1995. Empowerment and work teams. In G. R. Ferris, S. D. Rosen, \& D. T. Barnum (eds.), Handbook of human resource management (pp. 386-403). Oxford, England: Blackwell.

Lowin, A. 1968. Participative decision making: A model, literature critique, and prescriptions for research. Organizational Behavior and Human Performance, 3: 68-106.

Miller, K. I., \& Monge, P. R. 1986. Participation, satisfaction, and productivity: A meta-analytic review. Academy of Management Journal, 29(4): 727-753.

Motowidlo, S. J. 2000. Some basic issues related to contextual performance and organizational citizenship behavior in human resource management. Human Resource Management Review, 10(1): 115-126.

Myers, D. W. 1992. Human resource management: Principles and practices ( $2^{\text {nd }}$ ed.). Chicago: Commerce Clearing House.

Niehoff, B. P., Moorman, R. H., Blakely, G., \& Fuller, J. 2001. The influence of empowerment and job enrichment on employee loyalty in a downsizing environment. Group \& Organization Management, 26(1): 93-113.

Nunnally, J. C., \& Berstein, I. H. 1994. Psychometric theory (3 $3^{\text {rd }}$ ed.). New York: 
McGraw-Hill.

Nyhan, R. C. 1994. The interrelationships of organizational commitment, trust, and participatory decision-making practices in public organizations. Unpublished Ph.D. dissertation, Florida Atlantic University, Boca Raton, FL.

Pynes, J. E. 2004. Human resources management for public and nonprofit organizations ( $2^{\text {nd }}$ ed.). San Francisco: Jossey-Bass.

Sagie, A., \& Koslowsky, M. 2000. Participation and empowerment in organizations: Modeling, effectiveness, and applications. Thousand Oaks, CA: Sage Publications.

Salas, E., \& Cannon-Bowers, J. A. 2001. The science of training: A decade of progress. Annual Review of Psychology, 52: 471-499.

Smith, C. A. 1995. Human resource practices and policies as antecedents of organizational commitment. Unpublished Ph.D. dissertation, University of Western Ontario, London, Ontario, Canada.

Sparrowe, R. T., Liden, R. C., Wayne, S. J., \& Kraimer, M. L. 2001. Social networks and the performance of individuals and groups. Academy of Management Journal, 44(2): 316-325.

Steel, R. P., \& Lloyd, R. F. 1988. Cognitive, affective, and behavioral outcomes of participation in quality circles: Conceptual and empirical findings. The Journal of Applied Behavioral Science, 24(1): 1-17.

Tabachnick, B. G., \& Fidell, L. S. 2001. Using multivariate statistics. Needham Heights, MA: Allyn \& Bacon.

Tannenbaum, S. I., Mathieu, J. E., Salas, E., \& Cannon-Bowers, J. A. 1991. Meeting trainees' expectations: The influence of training fulfillment on the development of commitment, self-efficacy, and motivation. Journal of Applied Psychology, 76(6): 759-769.

Van Dyne, L., Cummings, L. L., \& McLean-Parks, J. 1995. Extra-role behaviors: In pursuit of construct and definition clarity (a bridge over muddied waters). In L. L. Cummings \& B. M. Staw (eds.), Research in organizational behavior (pp. 215-285). Greenwich, CT: JAI Press.

Van Dyne, L., Graham, J. W., \& Dienesch, R. M. 1994. Organizational citizenship behavior: Construct redefinition, measurement, and validation. Academy of Management Journal, 37(4): 765-802.

Van Dyne, L., \& LePine, J. A. 1998. Helping and voice extra-role behaviors: Evidence of construct and predictive validity. Academy of Management Journal, 41(1): 108-119.

Wagner, J. A. 1994. Participation's effects on performance and satisfaction: A reconsideration of research evidence. Academy of Management Review, 19(2): 312-330.

Wagner, J. A., \& Gooding, R. Z. 1987. Effects of societal trends on participation 
research. Administrative Science Quarterly, 32(2): 241-262.

Wellbank, H. L., Hall, D. T., Morgan, M. A., \& Hammer, W. C. 1978. Managing job progression for effective career development and human resource management. Personnel, 55(2): 54-65.

Williams, L. J. 1988. Affective and nonaffective components of job satisfaction and organizational commitment as determinants of organizational citizenship and inrole behaviors. Unpublished Ph.D. dissertation, Indiana University, Bloomington, IN.

Williams, L. J., \& Anderson, S. E. 1991. Job satisfaction and organizational commitment as predictors of organizational citizenship and in-role behaviors. Journal of Management, 17(3): 601-617.

\section{APPENDIX: MEASUREMENT ITEMS}

Participation (Delery \& Doty, 1996)

- Employees in this job are allowed to make many decisions.

- Employees in this job are often asked by their supervisor to participate in decisions.

- Employees are provided the opportunity to suggest improvements in the way things are done.

- Superiors keep open communication with employees in this job.

Empowerment (Nyhan, 1994)

- I have a great deal of latitude in performing my work tasks.

- My supervisor encourages me to monitor my own efforts.

- I have the authority to get my job done to the best of my abilities.

- I feel free to speak up when I disagree with a decision.

- The organization supports giving more authority downward in the organization.

Training (Delery \& Doty, 1996)

- Extensive training programs are provided for individuals in this job.

- Employees in this job will normally go through training programs every few years.

- There are formal training programs to teach new hires the skills they need to perform their jobs.

- Formal training programs are offered to employees in order to increase their promotability in this organization. 
Career development (Smith, 1995)

- My organization takes an interest in my career development or advancement.

- I think I am or will be given the opportunity to develop to my full potential in my organization.

- My organization provides me with sufficient challenge.

- I think there is a very good chance to get ahead in this organization in comparison to other (government) organizations.

In-role performance (William \& Anderson, 1991)

- I adequately complete assigned duties.

- I fulfill responsibilities specified in job description.

- I perform tasks that are expected of me.

- I meet formal performance requirements of the job.

- I engage in activities that will directly affect my performance evaluation.

- I neglect aspects of the job I am obligated to perform (R).

- I fail to perform essential duties (R). 